\title{
Equipping Mayan girls to improve their lives
}

\author{
Jennifer Catino \\ Population Council \\ Alejandra Colom \\ Population Council \\ Marta Julia Ruiz
}

Follow this and additional works at: https://knowledgecommons.popcouncil.org/departments_sbsr-pgy

Part of the Demography, Population, and Ecology Commons, Family, Life Course, and Society

Commons, Gender and Sexuality Commons, and the International Public Health Commons

How does access to this work benefit you? Let us know!

\section{Recommended Citation}

Catino, Jennifer, Alejandra Colom, and Marta Julia Ruiz. 2011. "Equipping Mayan girls to improve their lives," Promoting Healthy, Safe, and Productive Transitions to Adulthood Brief no. 5. New York: Population Council. 


\section{Equipping Mayan girls to improve their lives}

\section{Prepared by Jennifer Catino, Alejandra Colom, and Marta Julia Ruiz}

G uatemala's population is poorer, less educated, faster growing, and more ethnically diverse than most others in Latin America (Dries-Daffner et al. 2007). The country's fertility ( 3.6 children per woman) and infant mortality rates ( 30 deaths per 1,000 live births) are among the highest in the region (Figueroa et al. 2006; INE 2009). Nearly half of the Guatemalan population is indigenous, and more than 20 Mayan ethnic groups live in isolated rural areas with limited access to basic services such as water, sanitation, passable roads, schooling, and health care. Seventy-five percent of Mayans live in poverty (INE 2008a). Even though Guatemala has made progress toward achieving the Millennium Development Goals (MDGs) in the past few years, disparity persists in terms of access to services and general well-being between rural and urban populations. For example, although the national fertility rate decreased from 5.6 to 3.6 children per woman between 1987 and 2008, the rate among indigenous women is 1.4 higher than that among nonindigenous ( 4.5 versus 3.1). Education continues to affect fertility rates; women without education report having 5.2 children versus 2.3 among women with a high school education or more (INE 2009). Mayan girls are the country's most disadvantaged group, leading lives characterized by limited schooling, early marriage, frequent childbearing, social isolation, and chronic poverty (Hallman et al. 2006). Population Council researchers investigating access to social programs determined that few programs reach these girls. Building the health, economic, and social resources of this large, neglected group is both a moral imperative and essential for reaching the MDGs in Guatemala.

To help break the poverty cycle and enable Guatemalan girls to reach their full potential, the Population Council, in collaboration with a range of local and international partners, launched a program in 2004 to increase Mayan girls' social support networks, connect

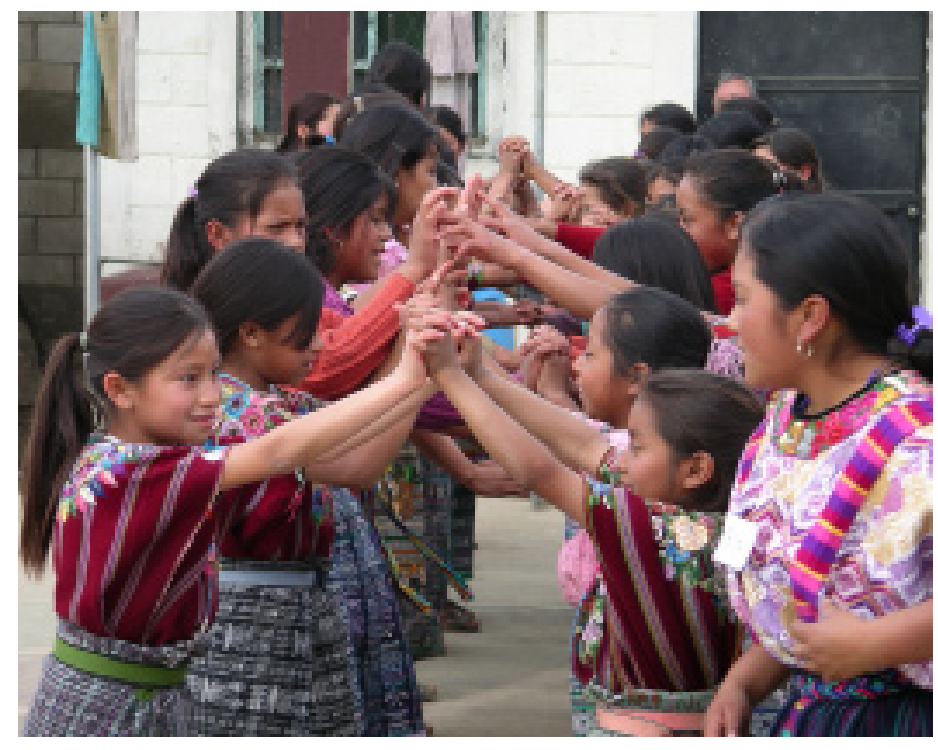

Older girls in the program become positive role models for young girls.

them with role models and mentors, build a base of critical life and leadership skills, and provide hands-on professional training and experience. The program has evolved and expanded in content and scope; ambitious plans are being made for it to become locally sustained and institutionalized to reach increasing numbers of girls.

Abriendo Oportunidades: National rural girls' program builds
social, health, and economic resources
The program, known as Abriendo Oportunidades ("Opening Opportuni-
ties"), makes critical investments in girls aged 8-18 to help them navi-
gate adolescent transitions successfully. By engaging community lead- 


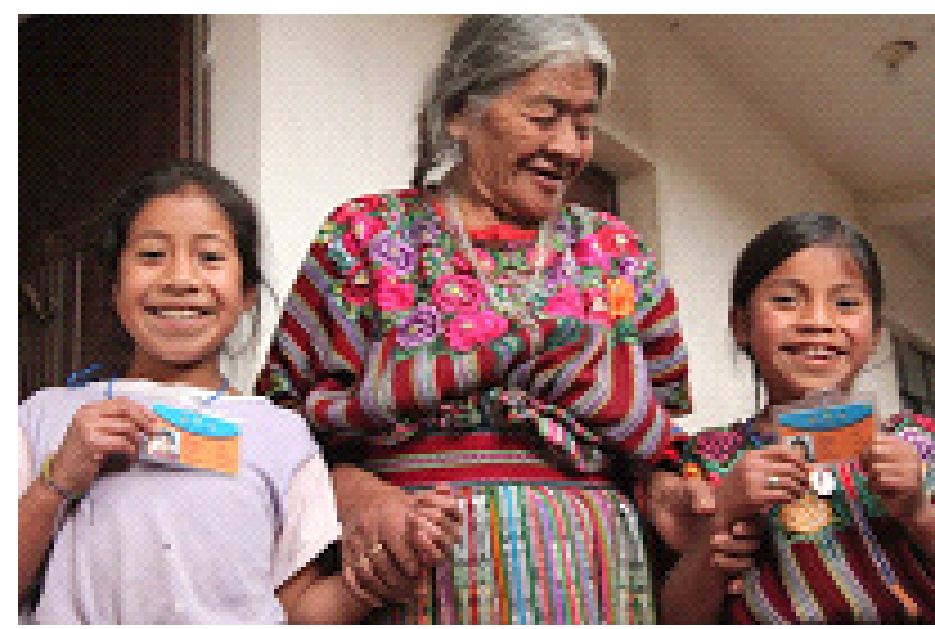

Providing Mayan girls with program-issued identification cards allows them to begin developing practical skills in civic participation

ers and training girls to run community-based girls' clubs, safe spaces are created in rural communities where girls come together to gain skills and build their social networks. As girls learn practical skills and take on leadership positions, families and communities are strengthened. Results from a recent evaluation of the program determined that:

- 100 percent of Abriendo girl leaders had completed the sixth grade, compared to 81.5 percent of girls nationally. Additionally, more Abriendo girls were in school at the close of the 2009-10 program cycle (72 percent), compared with the national average for indigenous girls ( 53 percent for those aged 13-15 and 29 percent among 16-17-year-olds) (USAID 2007);

- 97 percent of Abriendo girl leaders remained childless during the program cycle, compared with the 78.2 percent national average for girls in their age range (15-19) (Segeplan 2010);

- 94 percent of Abriendo girl leaders reported experiencing greater autonomy and feeling more comfortable expressing their opinions, and 84 percent said their role at home had improved during the program cycle;

- 88 percent of girl leaders reported having a bank account and 44 percent had obtained paid employment when the program cycle finished.

These results indicate that programs that identify and invest in the most vulnerable girls are showing signs not only of improving the well-being of individual girls but also of favorably changing social and gender norms and contributing to poverty reduction.

The program now works with seven Mayan ethnic groups in Guatemala (Kiche', Kaqchikel, Tzutuhil, Mam, Q'eqchi', Poqomchi', and
Chorti), has engaged more than 40 rural communities in six geographic regions of Guatemala, and has reached more than 3,500 indigenous girls aged 8-18-and it continues to expand. Girls in the program are divided into age cohorts (8-12 and 13-18) and participate in a life-cycle-specific program of activities. In each annual girls' club cycle, new peer mentors/ girl leaders are identified and trained; some older girls also apply for oneyear paid professional internships with local institutions in the public and private sectors. In turn, the girl leaders are supported to form and run clubs in rural communities. Girl leaders are also supported to establish and maintain collaborative relationships with local authorities.

Each young female mentor leads a club of approximately 40 girls per cycle. Workshops conducted with girls and their mothers include sessions on self-esteem, life skills, developing aspirations and planning for the future, sexual and reproductive health, and HIVI AIDS prevention. The program has connected the rural girls' clubs by establishing the Guatemalan Indigenous Girls Resource and Empowerment Network (GIGREN), which serves as a platform for indigenous girls to advocate for their needs and rights at both the community and the national level.

\section{After my personal and professional training, I began organizing girls' clubs in my community to teach groups of girls the subjects I had learned, to share my experience with them, to motivate them to dream about what they would like to be, and to work hard in order to reach their goals.}

—Girl leader, Alta Verapaz

With a vehicle for action and change, girls gain confidence and influence

As a recent evaluation demonstrates, the program's approach is achieving transformative changes among participants: girls' access to positive role models in the community is increasing, their sources of social support are growing, they are gaining confidence and self-esteem, and they are learning new skills. In addition, community attitudes about girls' social status, education, and involvement in public activities have become more positive and supportive.

The girls identify the creation of safe spaces near their homes as an important and much-appreciated aspect of the program. In these locations, girls are able to learn, share, and solve problems in the company of other girls from similar backgrounds. Participants experience increased autonomy and mobility in the community: they are allowed to visit friends' homes and attend field trips to other communities. They gain professional and leadership skills and develop more ambitious plans for their education and livelihoods, which engender greater respect from their own families and communities. 
Before, they [our parents] let my brother study, because he was a boy, let's say, but not me. But now l've demonstrated-I believe that I've shown my parents—that I could do it. Because before....my father told me when I left sixth [grade], "you're not going to study," and that's how it was. But when the project came, they gave me the opportunity to study and now I have many goals and I want to graduate; I want to keep studying.

—Girl leader, Sololá

Participation in the program also helps girls overcome doubts about their own abilities and alter conventional notions of gender in their communities. When parents and community leaders see girls take on new roles and get a sense of their capacity and potential, their ideas about girls and their opportunities start to change.

Creating these kinds of opportunities for girls in our communities helps them improve their quality of life. They discover and build skills and talents that help them create greater [educational, professional, health, and social] opportunities for themselves. This is especially important for girls, because they face the greatest barriers. We would love to see all of our children have opportunities like Abriendo Oportunidades.

\section{-Mother, Chimaltenango}

Girls also gain knowledge and life skills. They develop new perceptions of the meaning and consequences of interpersonal, domestic, and social violence. Many attain a more future-oriented outlook and are able to articulate more ambitious goals for themselves, such as delaying marriage, returning to school, and striving to start a small business. By receiving a stipend and learning basic financial capabilities, girls are encouraged to learn how to better manage money, think about savings, and prepare for productive livelihoods.

My goals are to finish primary school, graduate and become a teacher, to travel and earn my own money.

\section{-Girl participant, Totonicopán}

In the years since the program started, very few girl leaders have married and had children. For those who have done so, however, their ability to stay connected to the program and to move forward with broader life plans has not been impeded. Most of the girl leaders in the program return to school and extend their educational goals, which helps propel them to safe, secure, and productive livelihood options. As the program expands, it is integrating a greater focus on building girls' financial skills and help them develop strategies for saving and gaining access to value chains. These efforts are intended to help girls become financially literate and put them on a path to greater opportunities for dignified income generation.

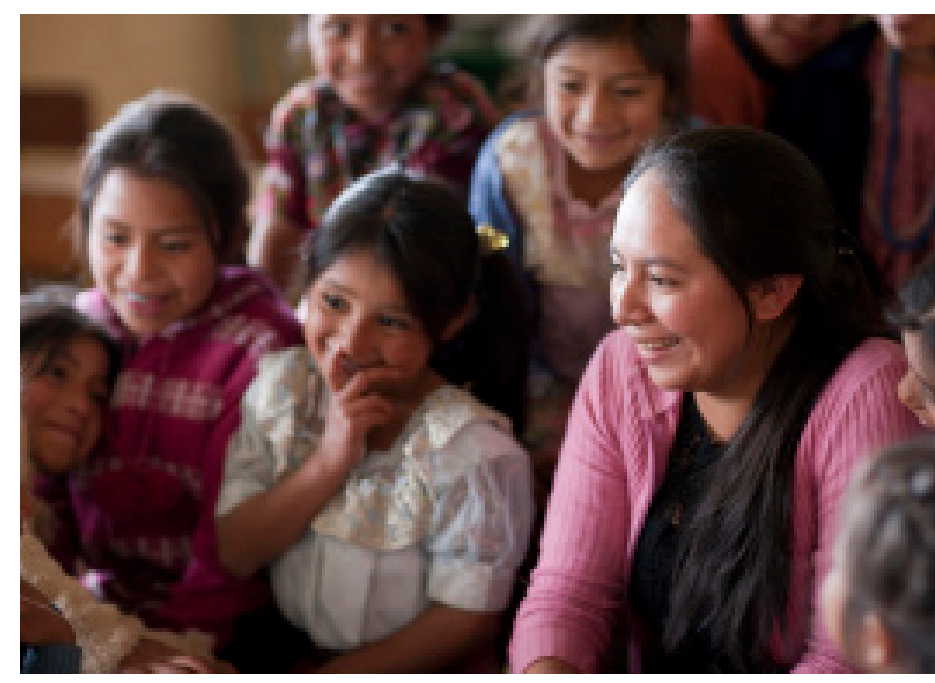

Program mentors teach girls leadership and life skills.

Discussions with girls and parents suggest that girls' new social connections and skills will have long-term benefits, increasing their access to jobs and raising their status in the community.

Thanks to Abriendo Oportunidades, girls and families see the important relationships between health, education, and work. Girls used to drop out of school because they didn't think their education would help them find jobs and live a better life. Now we can see the importance of education for girls.

\section{-Father, Totonicopán}

Community attitudes about the roles of girl leaders have changed over time. By developing skills that previously did not exist in the community, such as computer skills, public-speaking, leadership, and community-organizing expertise, the girls become more appreciated and valued by their families and communities.

When they [community members] need something, they call me and they say, "if you could do us the favor of helping with the young people, to carry out an activity with them." Everything has changed for me since I was in the program.

—Girl leader, Chimaltenango

Most of the girls who have participated in Abriendo Oportunidades remain connected to each other and the program through the national rural girls' network, receiving ongoing benefits and contributing to the sustainability and growth of the program. Graduates have been hired to take up supervisory positions in the program expansion. Many have gone on to continue their education and find paying jobs in the public and private sectors. Furthermore, most of the young women remain in or return to their communities, acting as leaders, advocates, and an example of and catalyst for social change. Still others have had the chance 
to represent themselves and other girls like them in national and international policy settings, giving voice to the otherwise voiceless.

Current emphasis in the program is on the prevention of violence against girls and young women. Despite the wide and increasing prevalence of social and gender violence in Guatemala, little is being done in the area of prevention in general, and less with a focus on rural indigenous girls. In response, Abriendo is working with the public sector and local NGO partners to train girl leaders to address violence at the community level, helping girls and young women keep themselves safe and know what to do if needs arise. Specific activities include training and placing young female leaders as interns with service providers addressing gender violence in rural communities; "safety mapping" with girls to understand where, when, and with whom they feel safe and unsafe; and designing strategies with them to mitigate risks. The girls' clubs are used as a base to educate and promote the right to safety and security and to equip and support girls and young women to break cycles of violence in their homes and communities.

\section{References and related publications}

Colom, Alejandra, Marta Julia Ruiz, Jennifer Catino, Kelly Hallman, Sara Peracca, and Kristen M. Shellenberg. 2005. "Voices of vulnerable and underserved adolescents in Guatemala." Guatemala City: Population Council.

Dries-Daffner, Ingrid, Kelly Hallman, Jennifer Catino, and Karla Berdichevsky. 2007. "Guatemala," in Jeffrey Jensen Arnett (ed.), International Encyclopedia of Adolescence. New York: Routledge.

Figueroa, Werner, Felipe Lopez, Lisa Remez, Elena Prada, and Joanna Drescher. 2006. "Early childbearing in Guatemala: A continuing challenge." In Brief, 2006 Series, No. 5. New York: Guttmacher Institute.

Hallman, Kelly, Sara Peracca, Jennifer Catino, and Marta Julia Ruiz. 2006. "Multiple disadvantages of Mayan females: The effects of gender, ethnicity, poverty and residence on dducation in Guatemala." Policy Research Division Working Paper No. 211. New York: Population Council.

_. 2007. "Indigenous girls in Guatemala: Poverty and location," in Maureen Lewis and Marlaine Lockheed (eds.), Exclusion, Gender and Schooling: Case Studies from the Developing World. Washington, DC: Center for Global Development.
Instituto Nacional de Estadística (INE) [National Statistical Institute]. 1999. Encuesta Nacional de Salud Materno-Infantil (National Survey of Maternal and Infant Health), 1998-1999. Guatemala City: INE.

- 2008a. Encuesta de condiciones de vida (Living Standards Measurement Survey), 2006. Guatemala City: INE.

2008b. Mujeres y hombres en cifras (Men and women in numbers), Guatemala City: INE.

. 2009. Encuesta Nacional de Salud Materno-Infantil (National Survey of Maternal and Infant Health), 2008-09. Guatemala City:INE.

Segeplan. 2010. Tercer informe de avances en el cumplimiento de los objetivos de desarrollo del milenio (Third report on the progress towards achieving Global Millennium Goals), 2009. Guatemala City: Segeplan.

Smith, Maria Baños, Marta Julia Ruiz, Luisa Maria Mazariegos, Jennifer Catino, and Guille Herrera. 2004. "Entendiendo y respondiendo a la violencia doméstica en comunidades indígenas de Guatemala" [Understanding and responding to domestic violence in Guatemala's indigenous communities]. Guatemala City: Population Council.

USAID. 2007. "Equidad de la Educación en Guatemala." Serie de Investigaciones Educativas vol. 4. Guatemala City: USAID.

\section{Donors}

Bill \& Melinda Gates Foundation, UK Department for International Development (DFID), Nike Foundation, Partridge Foundation, Research Triangle Institute/ Alianzas/USAID, Summit Foundation, United Nations Population Fund (UNFPA), United Nations Trust Fund (UNTF)/United Nations Fund for Women (UNIFEM), William and Flora Hewlett Foundation

\section{Partner institutions}

Asociación Renacimiento, Cooperativa para el Desarrollo Rural del Occidente (CDRO), Defensoria de la Mujer Indígena (DEMI), EngenderHealth, Federación de Salud Infantil y Reproductiva de Guatemala (FESIRGUA), Centro de Información, Capacitación y Apoyo a la Mujer (CICAM) Kiej de los Bosques, Mercy Corps, Pies de Occidente, Proyecto para el Desarrollo Sostenible de las Comunidades Ak'aba'al (Prodesca), Asociación Ajpatnar Chorti.

\section{(2) Population Council}

The Population Council changes the way the world thinks about critical health and development issues. We seek to understand the causes and consequences of gender inequality and the disparities in opportunity that arise during adolescence. We provide the evidence for better on-theground programs and policies that ensure successful and productive transitions to adulthood in developing countries. www.popcouncil.org

(c) 2011 The Population Council, Inc. 